\title{
MENINGKATKAN PENDAPATAN MASYARAKAT SAAT PANDEMI MELALUI PENATAAN PASAR TRADISIONAL (PASAR BSI, BOGOR TIMUR)
}

\author{
Penulis Pertama ${ }^{1}$ JM. Joko Priyono Santoso Penulis Kedua ${ }^{2}$ Doddy Yuwono \\ ${ }^{1}$ Jurusan Arsitektur, Fakultas Teknik, Universitas \\ Tarumanagara jokop@ft.untar..ac.id \\ $2{ }^{1}$ Jurusan Arsitektur, Fakultas Teknik, Universitas Tarumanagara \\ doddyyy@ft.untar.ft.id
}

\begin{abstract}
In this Covid -19 situation or not, effort to improve people's welfare for must be carried out. The availability of traditional market stall on Jalan Kol Achmad Syam, east Bogor is very limited, but the residents of Baranang Siang and Katulampa still use the market for household shopping in the Covid-19 situation either morning or night. The minimum number of kiosks is caused by the arrangement that is no optimal. The pattern of movement of market visitors is also two-way and some even from kiosks pocket-some so that it has the potential to increase physical contact. The more kiosks are built and provided, the more chance people or vendor doing business, this is the goal of improving the welfare of residents can be achieved. In addition, the purpose of this arrangement can also be realized for locations that have the same or similar character. The descriptive method is very well supported by the SNI Traditional Market approach and Kevin Lync's theory. This method is able to produce a large number of market stalls. The arrangement pattern is also able to separate groups of vendor according to function, including new dishes for direct consumtion (fresh food) so as to support health programs.
\end{abstract}

Key word :To arrangement, market, East Bogor

\begin{abstract}
ABSTRAK
Dalam situasi Covid 19 atau tidak, usaha peningkatan kesejahteraan masyarakat harus tetap dilakukan. Ketersediaan kios pasar tradisional di jalan Kol Achmad Syam Bogor Timur sangat minim, namun warga Baranang Siang Indah dan Katulampa tetap memanfaatan pasar untuk berbelanja rumah-tangga dalam situasi Covid19 baik pagi atau malam. Minimnya jumlah kios disebabkan oleh penataan yang tidak optimal. Pola pergerakan penggunjung pasar juga dua arah bahkan ada yang membentuk kantong kios sehingga berpotensi peningkatan kontak fisik. Semakin banyak kios dibangun akan semakin banyak tempat usaha yang bisa dilakukan oleh warga, dengan demikian tujuan untuk meningkatkan kesejahteraan warga dapat tercapai. Selain itu tujuan penataan ini bisa diwujudkan pula bagi lokasi-lokasi yang memiliki karakter sama atau serupa. Metode diskriptif sangat terdukung dengan adanya pendekatan SNI Pasar Tradisional dan teori Kevin Linc. Metode tersebut mampu menghasilkan jumlah kios pasar lebih banyak jumlahnya. Pola penataan juga mampu memisahkan kelompok kios sesuai fungi, termasuk masakan baru untuk langsung dikonsumsi (fresh food) sehingga mendukung program kesehatan
\end{abstract}

Kata kunci: Penataan, Pasar, Bogor Timur

\section{PENDAHULUAN}

Kebutuhan akan tempat belanja (pasar) menjadi prioritas utama untuk hidup masyarakat, demikian juga untuk warga Bogor apalagi di tengah masa pandemi covid 19. Warga dari beberapa permukiman yang tidak direncanakan dan direncanakan yang berjumlah lebih dari 7 (tujuh) permukiman berada di samping atau di akses melalui jalan Kol Achmad Syam. Salah satunya adalah Baranang Siang Indah (BSI), masuk dalam Kecamatan Bogor Timur Kota Bogor Sudah cukup lama dan tujuh permukiman ini berada di sekitar jalan Kol Achmad Syam namun belum memiliki fasilitas perbelanjaan natural yang memadai. Tersedia pasar darurat atau pasar tradisional dengan kapasitas kios kurang dari 10 kios semi permanen ditambah satu swalayan. Kios pedagang sayur dan kebutuhan sehari hari hanya ada satu, merangkap berjualan dagangan basah. Masakan cepat saji dengan berbagai variant hanya 4 (empat) 
termasuk pedagang bubur ayam dan gado gado. Penguasaan tempat menunjukan hanya sebagian masyarakat yang bisa membuka usaha. Kebutuhan hidup sehari -hari hanya tercukupi dengan pedagang sayur dengan gerobag dorong, pedagang sayur bermotor atau pedagang gendongan. Warga harus menempuh perjalanan 30 menit lebih (hanya untuk sebuah kota kecil) menuju pasar yang sudah disiapkan oleh Pemerintah Kota Bogor (PD. Pasar Bogor dan Pasar Surya Kencana) dengan kendaraan pribadi. Radius pencapaian relativ pendek tetapi karena pola jalannya yang berbelok belok sehingga membutuhkan waktu yang cukup lama. Dari BSI menuju Pasar Jaya Bogor tersedia angkutan umum dengan nomor 11A warna hijau. Rendahnya frekuensi commuter dan perjalanan sesuai rute membutuhkan waktu yang relative cukup lama.

Mengacu pada data Bogor Dalam Angka 2018, menunjukan bahwa pasar tidak menjadi prioritas utama karena tidak tercermin dengan jelas dan terstruktur dalam buku Bogor Timur Dalam Angka 2018. Perkembangan wilayah perdagangan bersifat linear dan menempati sepanjang jalan yang memungkinkan untuk perdagangan termasuk jalan Kol Achmad Syam.

Pasar untuk warga Baranang Siang dan Katulampa adalah pasar yang sengaja dilahirkan atau diharapkan disiapkan untuk memenuhi kebutuhan hidup warganya, namun dengan penataan dan kapasitas yang sangat terbatas.

Lokasi pasar yang dijadikan usulan merupakan pasar sementara dan berada di simpang tiga antara jalan Kol Achmad Syam (dikenal sebagai jalan baru) dengan jalan Baranang Siang Indah yang semula merupakan lokasi simpang empat (jalan Kol Achmad Syam merupakan jalan utama ; jalan Baranang Siang Indah dan jalan Arcadomas sebagai jalan penghubung antar Lingkungan memotong jalan Kol Achmad Syam).

\section{METODE PELAKSANAAN PKM}

Pelaksanaan PKM dengan menggunakan metode diskriptif-ekplanatoris dan metode analisissintesis pada saat mekakukan desain dengan mempertimbangan beberapa teori tentang analisis site karya Kevin Lync dan tulisan-tulisan jurnal tentang pasar. Metode kualitatif juga digunakan dalam proses PKM. Metode diskriptif dan ekplanatoris digunakan saat harus melakukan penelusuran pasar tradisonal versi SNI 8152 tahun 2015 tentang pasar tradisional, agar hasil yang ingin dicapai tidak mandul dan kaku terhadap SNI 8152. Fleksibilitas pasar menjadi terasa dalam dunia arsitektur dan ini yang kemudian perlu didiskripsikan kembali. Eksplanantoris digunakan untuk melakukan penataan dan menjelaskan kembali bagaimana bentukan pasar nantinya sehingga sesuai dengan kebutuhan saat ini.

Penempatan kios-kios perdagangan yang harus disesuaikan dengan arus pergerakan pengguna, bagaimana kenyamanan termal dan visual bisa dicapai serta melakukan zonasi kios yang ditempatkan sesuai SNI yang dimaksud di atas.

Metode analisis dan sintesis digunakan saat memulai pendataan jumlah pedagang, jenis dagangan, waktu kegiatan dikaitkan dengan data kependudukan, bersamaan dengan survey lapangan yang menggunakan metode kualitatif sederhana.

Analisis digunakan pula pada saat mulai kegiatan penataan karena harus melakukan sinkronisasi antara pertumbuhan jumlah kios dan kapasitas site sehingga hasil penataan tidak padat dan masih fleksibel untuk pertukaran udara. Analisis juga dipakai untuk menentukan material dan bentuk bangunan agar masih memiliki nilai nilai kelokalan, agar Bogor juga masih bisa dijadikan alat untuk mempromosikan Arsitektur Sunda dan Tropisnya.

Analisis kualitatif lebih dipilih karena diharapkan dari PKM yang dimulai dengan penelitian sederhana sebelumnya akan menghasilkan karya arsitektur yang lebih menekankan kepada kualitas kepekaan atas kebutuhan pemakai, sehingga tidak bias dilakukan dengan menjeneralisasikan. Jika sendainya hasil PKM ini akan dipakai ditempat lain bukan berarti 
menjadikan hasil PKM ini bisa digeneralisasikan tetapi dijadikan sebuah tipologi.

\section{HASIL DAN PEMBAHASAN}

Hasil pengamatan di lapangan menunjukan kompleks seperti Baranang Siang Indah, Villa Duta, Bogor Lake Site (WIKA), Ponpes All Inayah, Parahyangan Pajajaran Regency, Griya Bogor Raya, Perumahan Kompleks Indah Regency dan permukiman warga yang tumbuh secara natural tanpa perencanaan dan perancangan oleh urban planner atau pengembang, menempati sisi-kiri dan kanan jalan Kol Achmad Syam (gambar 1).

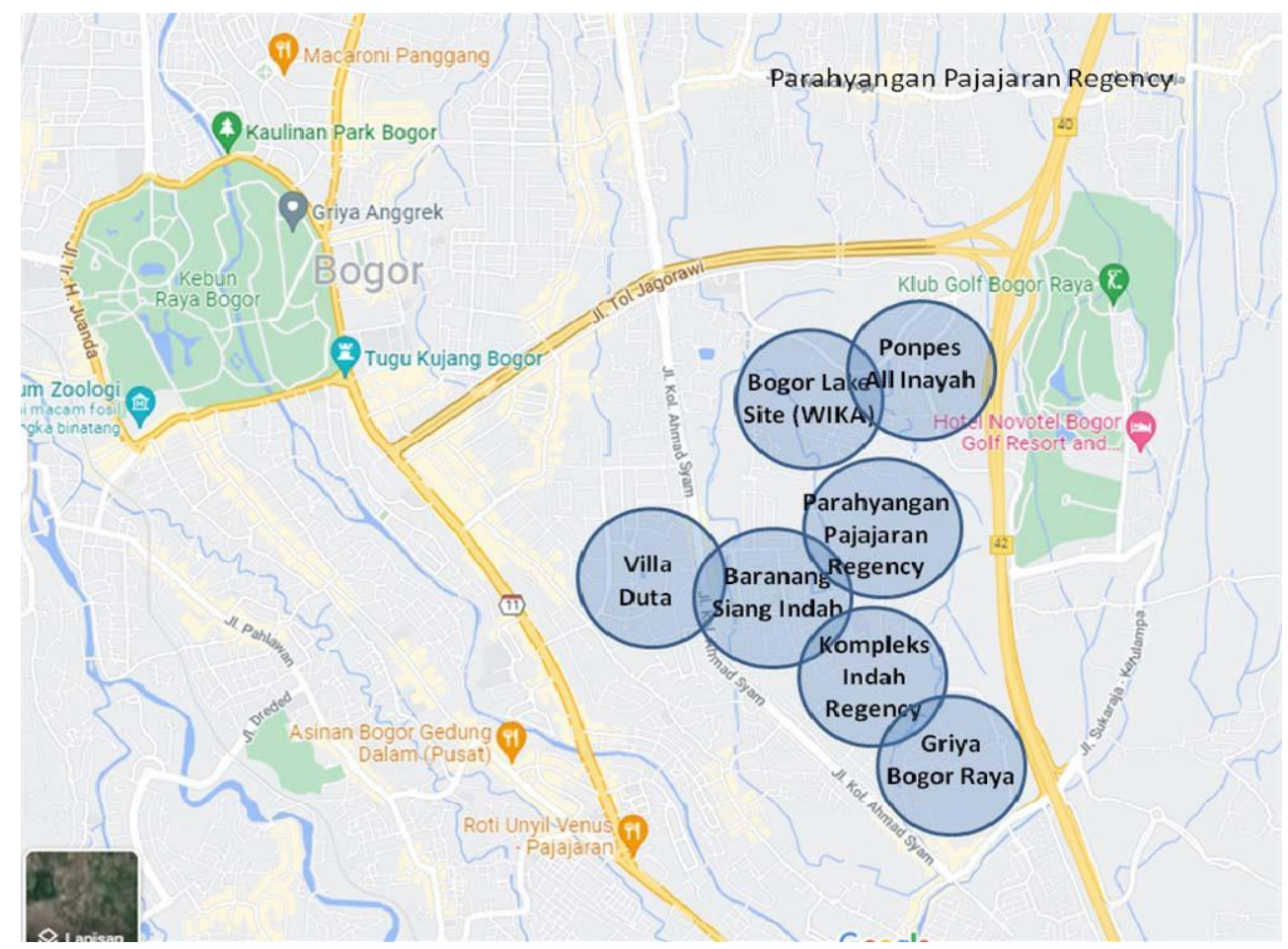

Gambar 1. Posisi beberapa perumahan menempati sisi-kiri dan kanan jalan Kol Achmad Syam, sumber : Google Eart-Modifikasi

Sistem transportasi menjadi bagian penting untuk sebuah perjalanan termasuk dari rumah menuju pasar, pengaruhnya terletak pada kemampuan membawa hasil belanjanya. Dalam kasus PKM ini masyarakat masih diberi kemudahan karena angkutan umum bersedia door to door saat pulang. Probem yang terjadi angkutan umum tidak memiliki frekuensi yang tetap. Lokasi pasar berada pada titik bulat di antara Kompleks Villa Duta dan Kompleks BSI, sedangkan lokasi PD Pasar Jaya Bogor terletak pada dua titik bulat yang lain (terlihat pada gambar 2). 
Kompleks Villa Duta Kompleks BSI

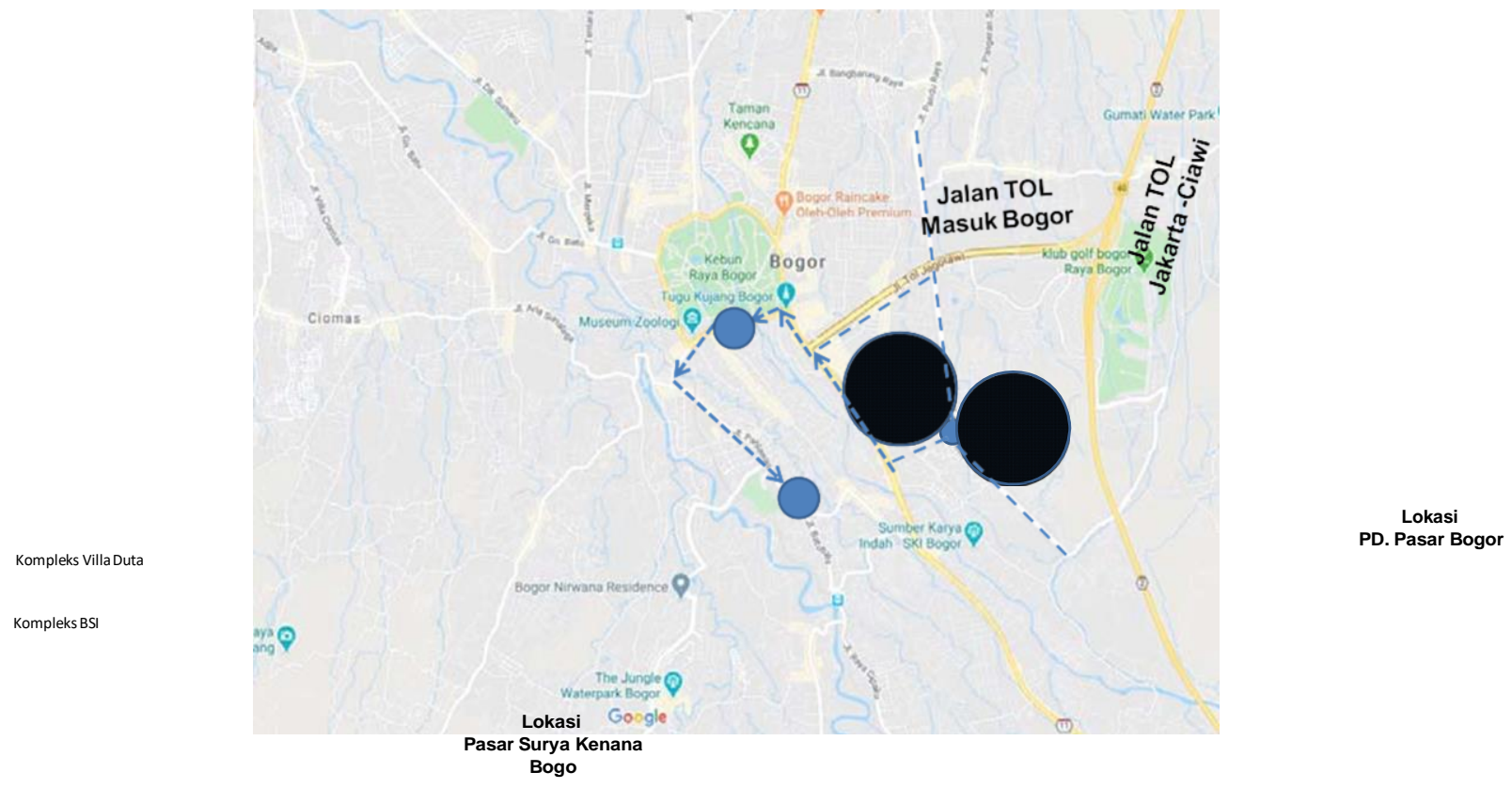

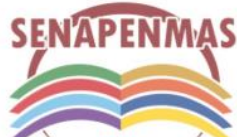

2021

Gambar 2. Peta lokasi pasar utama dengan lokasi kompleks perumahan BSI dan Villa Duta (Sumber Google Map yang dikembangkan)

Lokasi tumbuh bersama dengan fasilitas perdagangan untuk kebutuhan rumah tangga seharihari karena menempati jalur hijau, dapat dilihat pada gambar 2.

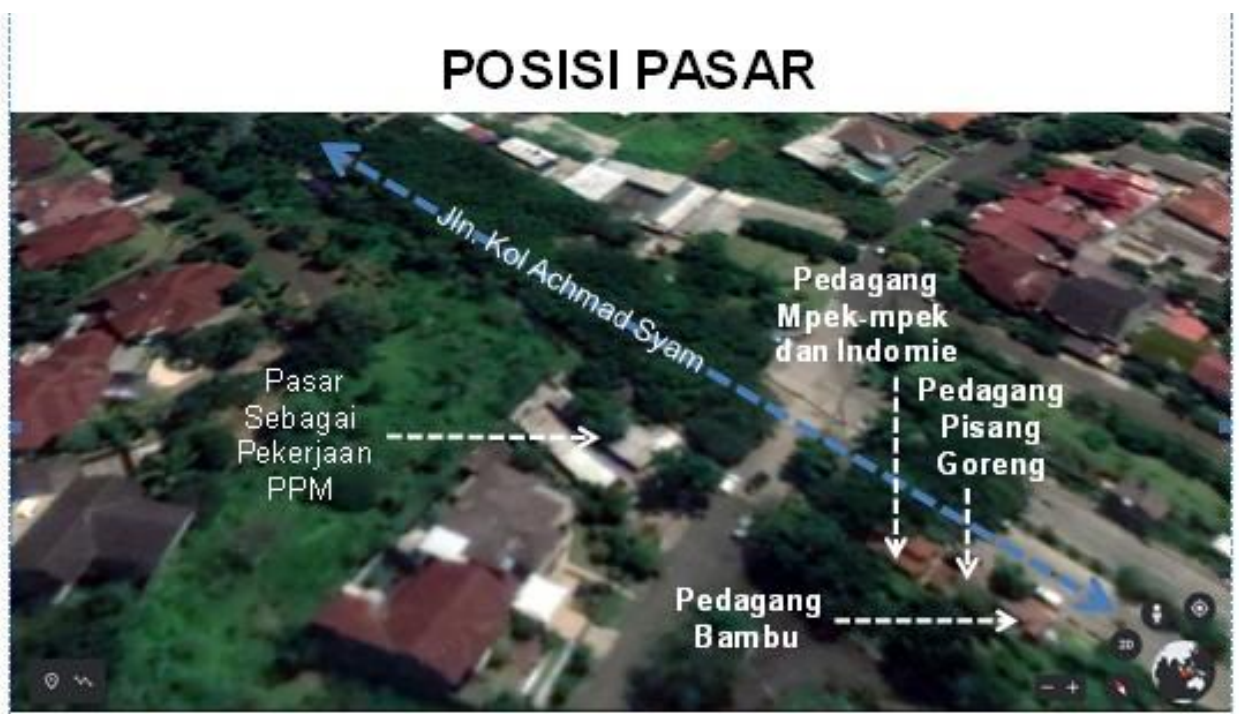

Gambar 3. Titik lokasi pasar berada di jalan Kol Achmad Syam dan beberapa tempat dagang lain.

Sumber: Google Map yang dikembangakan dengan lokasi kompleks perumahan BSI dan Villa Duta (Sumber Google Map yang dikembangkan)

Selain tumbuhnya pedagang pisang goreng, mpek-mpek tumbuh perdagangan lainnnya seperti pada gambar 4.5.6.7 


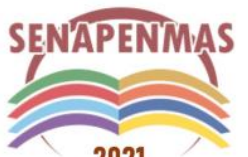

2021

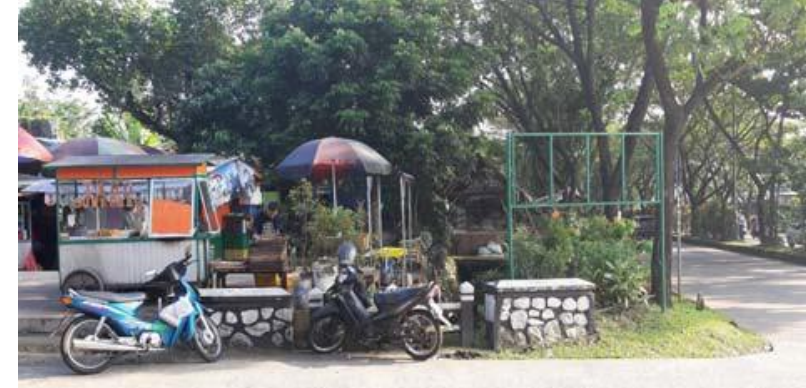

Gambar 4. Sudut pasar dengan saluran Riol Kota saluran Riol

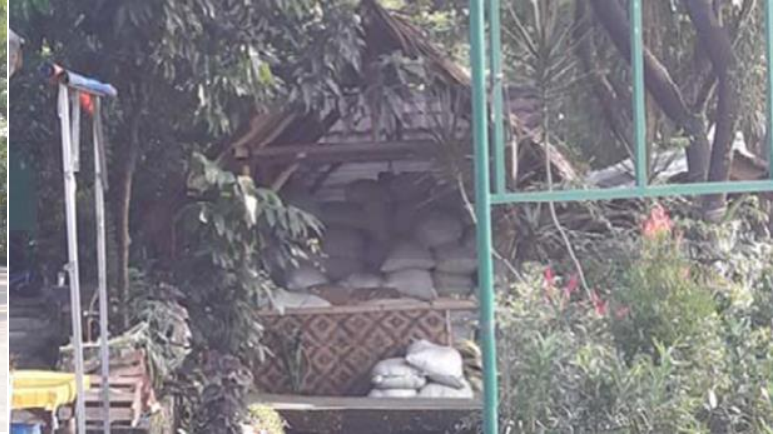

Gambar 5. Pedagang Pupuk berada, diatas

Kota

Gubuk penjual pupuk dan peralatan kebun terlihat lebih jelas dengan menempatkan diri di atas jembatan sungai yang brmanfaat untuk penyeberangan orang untuk ke pasar. Perkembangan jenis dagangan semakin banyak fariannya, mendorong sepanjang wilayah ini akan menjadi pergadangan linear. Salah satu pemandangan kios penjual tanaman yang mulai menyebar sepanjang tepi kri dan kanan jalan Kolonel Achmad Syam, bahkan mulai ramai dengan memarkirkan mobil/motor untuk berjualan (buah, tissue, masker dan lainnya sejenis). Kelurahan yang sangat berpengaruh terhadap peningkatan dan penggunaan Pasar di Baranang Siang Indah

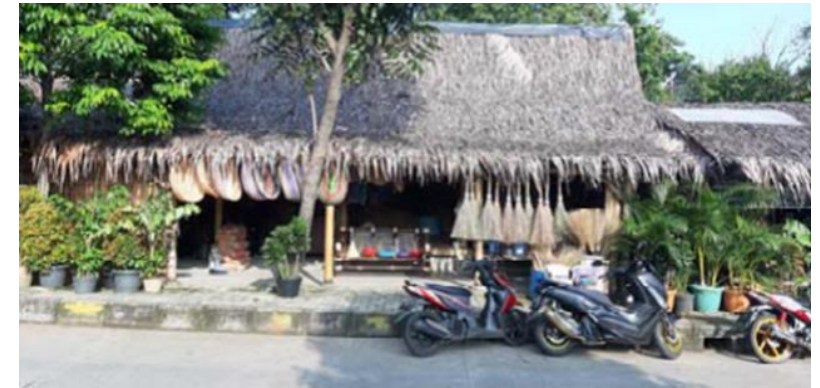

Gambar 6. Pedagang peralatan kebun tradisional

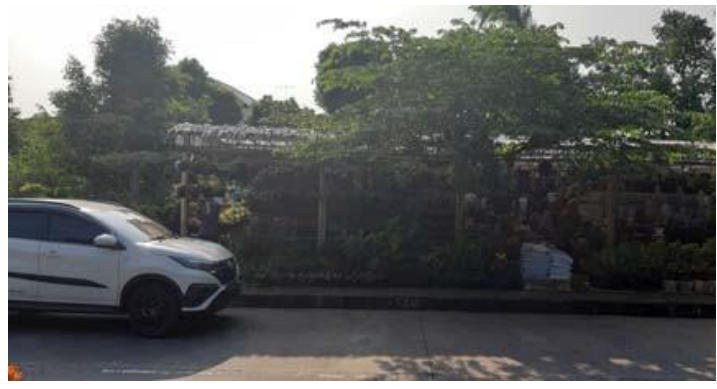

Gambar 7. Pedagang bunga dan kelengkapannya

Dua Kelurahan yuang memiliki kepadatan dan luas lahan yang terbesar, lihat tabel 1.

Tabel 1. Jumlah RT dan RW pada kelurahan baranang Siang Indah dan Katulampa

\begin{tabular}{llccc}
\hline No & Kelurahan & Luas Wil Km & Jumlah RW & Jumlah RT \\
\hline 1 & Katulampa & 491 & 21 & 121 \\
\hline 2 & Baranang Siang Indah & 235 & 14 & 83 \\
\hline
\end{tabular}

Sumber Data : Laporan Tahunan Kelurahan Katulampa Copy @2019

Kepadatan penduduk :

Tabel 2: luas Kelurahan dan kepedatan penduduk tervbesar yang memanfaatkan pasar BSI.

\begin{tabular}{|c|c|c|c|c|c|c|}
\hline \multirow{2}{*}{ No } & \multirow{2}{*}{ Kelurahan } & \multirow{2}{*}{ Luas Wil $\mathrm{Km}^{2}$} & \multicolumn{2}{|c|}{ Jumlah Penduduk } & \multicolumn{2}{|c|}{ Kepadatan } \\
\hline & & & 2.016 & 2.017 & 2.016 & 2.017 \\
\hline 1 & Katulampa & 491 & 33.484 & 34.515 & 6.820 & 7.030 \\
\hline 2 & Baranang Siang Indah & 235 & 27.324 & 27.290 & 11.627 & 11.613 \\
\hline
\end{tabular}




\section{Konsep penataan}

Tersedianya luas tanah yang hanya mencapai lebih kurang 28x28m2. Menempati lahan fasilitas umum (daerah hijau) maka desain pasar akan lebih tepat sebagai pasar sementara namun bisa bertahan lama (semi permanen) sambil menunggu keputusan terakhir ari pemerintah.

Penggunaan lahan $784-159 \mathrm{~m}^{2}(\mathrm{GSB})$ sisa tanah $625 \mathrm{~m}^{2}$. Fungsi tanah fasilitas umum (jalur hijau) maka digunakan KDB sebesar $60 \%$ dan $40 \%$ buat penghujauan, luas yang diperoleh $375 \mathrm{~m}^{2}$. Pemanfaatan lahan kios $70 \%$ dan $30 \%$ untuk sirkulasi satu arah, luas kios yang bisa terbangun $262.5 \mathrm{~m}^{2}$. Fungsi lain untuk servis area $30 \%\left(78 . \mathrm{m}^{2}\right)$. lahan sisa untuk kios $183.75 \mathrm{~m}^{2}$ Hasil dialog dan survey pasar dalam PKM ini ditetapkan ada 2 varian ukuran kios yaitu $2 \times 2 \mathrm{~m}^{2}$ dan $2 \times 3 \mathrm{~m}^{2}$.

Menentukan pola sirkulasi berdasarkan pergerakan dan kebutuhan penduduk atas barang yang dibutuhkan. Arsitektur Tropis yang adaptiv harus menjadi dasar Perancangan Wujud bangunan (building form), Konsep bangunan yang dipilih adalah arsitektur tradisional Sunda yang sudah banyak dikenal yaitu Tonggoh, Cigenclang dan Palastra, untuk membangun kembali Citra Sunda pada bangunan pasar Tradisional ini.

Konsep tradisioanl kontemporer dicapai dengan supper impose untuk mendapatkan hasil stackt effect pada ruang dalam dan dibantu dengan cross ventilation yang diperoleh dari perbedaan ketinggian. Konsep supper impose akan menghasilkan ruang yang cukup flesibel dalam memanfaatkan ruang dan mendapatkan effisiensi dalam penggunaan enerji listrik meskipun desain pasar hasil penataan menggunakan konsep ruang yang sudah tidak seterbuka seperti apa yang terjadi sebelumnya.

Pola parkir. Sistem parkir akan menjadi lebih baik jika mengikuti peraturan yang ada, artinya menegakkan aturan yang telah ditetapkan oleh pemerintah demi keamanan dan keselamatan pemakai jalan secara umum.

\section{Konsep struktur dan material.}

Untuk mendapatkan hasil penataan dan memiliki konsep green building maka selubung bangunan dipilih material terbarukan (kulit bambu anyam) karena jejak ekologisnya sangat murah dan benar benar terbarukan. Proses pekerjaan atau produksi dengan cara manual yang akan mendorong untuk membuka lapangan kerja (konsep berkelanjutan)

Sistem struktur digunakan sistem konvensional dengan merentangkan kaki kaki segitiga dengan bahan bambu dimana di ujung atas dibangun sebuah konsep kekakuan (gambar 8)

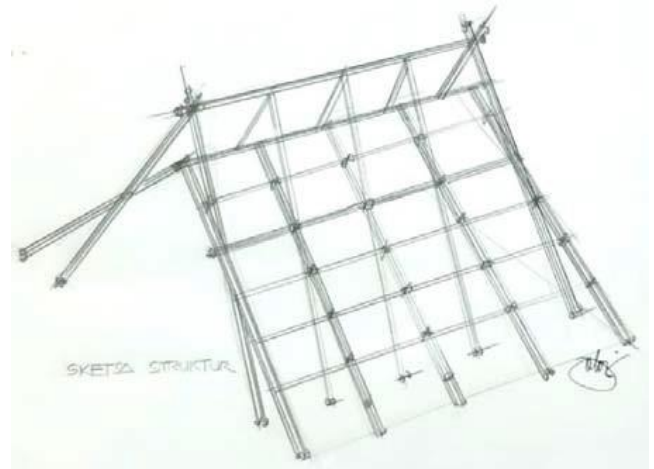

Gambar 8. Sistem struktur yang ditawarkan

\section{Konsep penataan}

Konsep penataan dengan mempertimbangan SNI 8152 tahun 2015dan dengan pendekatan teory Kevin lync menhasilkan beberapa penataan seperti pada gambar 9, 10 dan 11 di bawah 


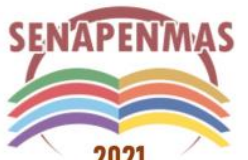

2021
Seminar Nasional Hasil Penelitian dan Pengabdian Kepada Masyarakat 2021

Pengembangan Ekonomi Bangsa Melalui Inovasi Digital Hasil Penelitian dan Pengabdian Kepada Masyarakat Jakarta, 21 Oktober 2021

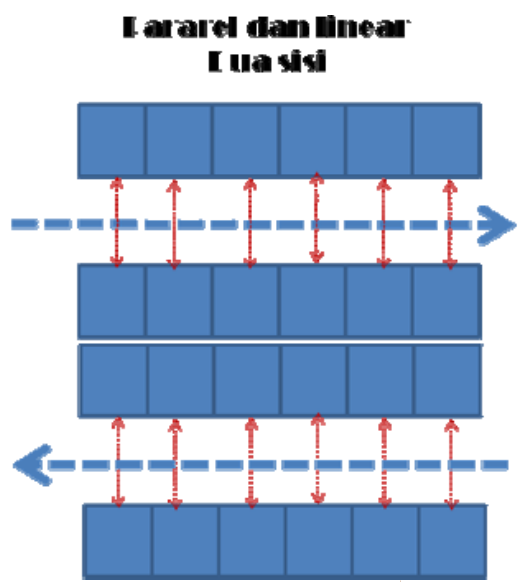

Gambar 9. Pola penataan kios secara pararel dan linear dua sisi

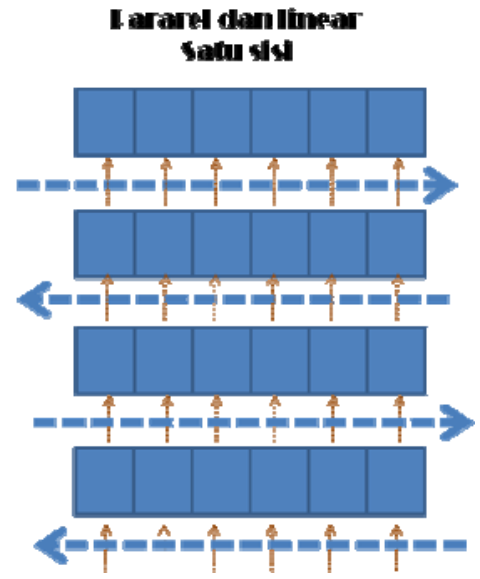

Gambar 10. Pola penataan kios secara pararel dan linear satu sisi
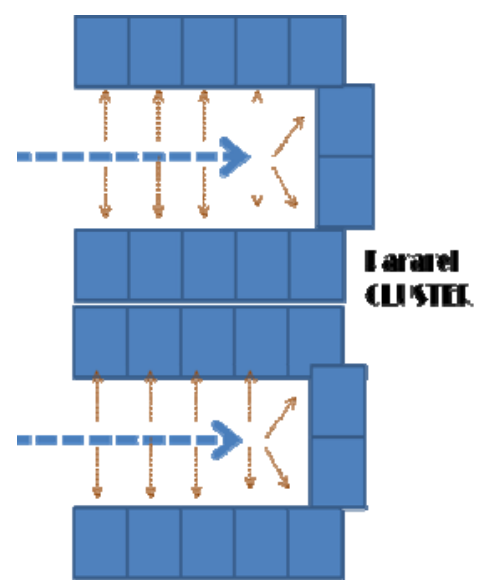

Gambar 11. Pola penataan kios dengan bentuk Cluster

Mengingat pertimbangan kesehatan baik pengelompokan jenis dagangan dan sitrkulasi pngunjung maka diputuskan dengan membuat Zonning agar tidak terjadi kesulitan pergerakan, terlihat pada gambar 12. Hasil alhir susunan masa bangunan dapat terlihat pada gambar 13. 


\section{Konsep Zonasi}

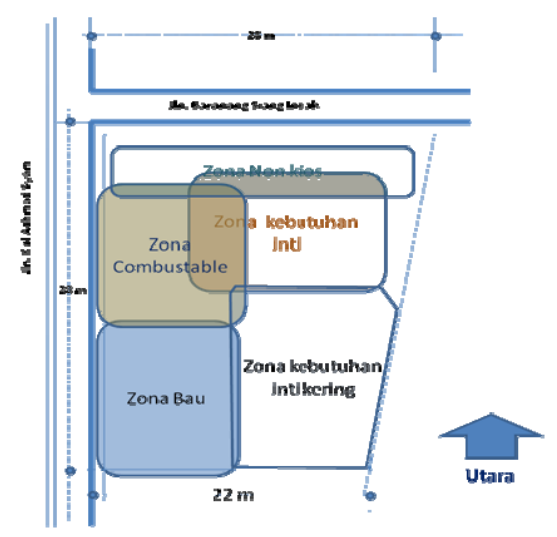

Gambar 12. Zonasi penempatan kios

\section{Hasil Penataan}

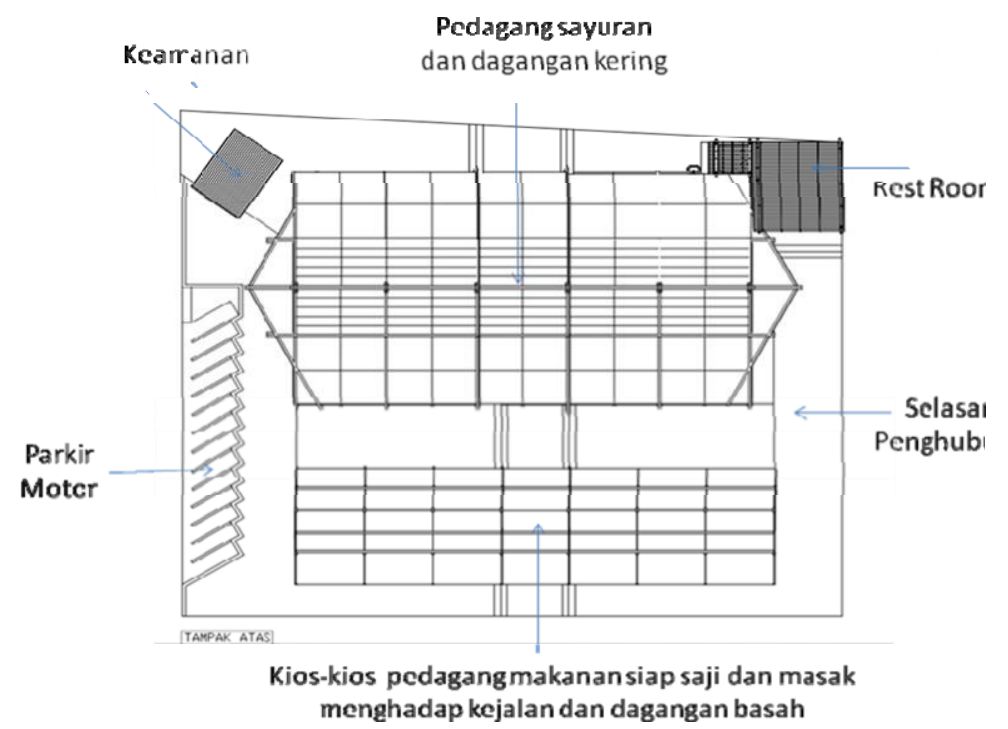

Gambar 13. Site Plan Bangunan Pasar

Untuk memperjelas hasil panataan dapat dilihat pada gambar Denah pasar (gambar 14) yang menunjukan orientasi kios-kios dan dibuat koridor pemisah yang cukup lebar untuk mengamankan sirkulasi pemakai. Sedangkan wajah bangunan dapat dilihat pada gambar 15 dan 16. 


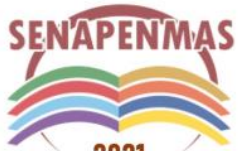

2021
Seminar Nasional Hasil Penelitian dan Pengabdian Kepada Masyarakat 2021 Pengembangan Ekonomi Bangsa Melalui Inovasi Digital Hasil Penelitian dan Pengabdian Kepada Masyarakat Jakarta, 21 Oktober 2021

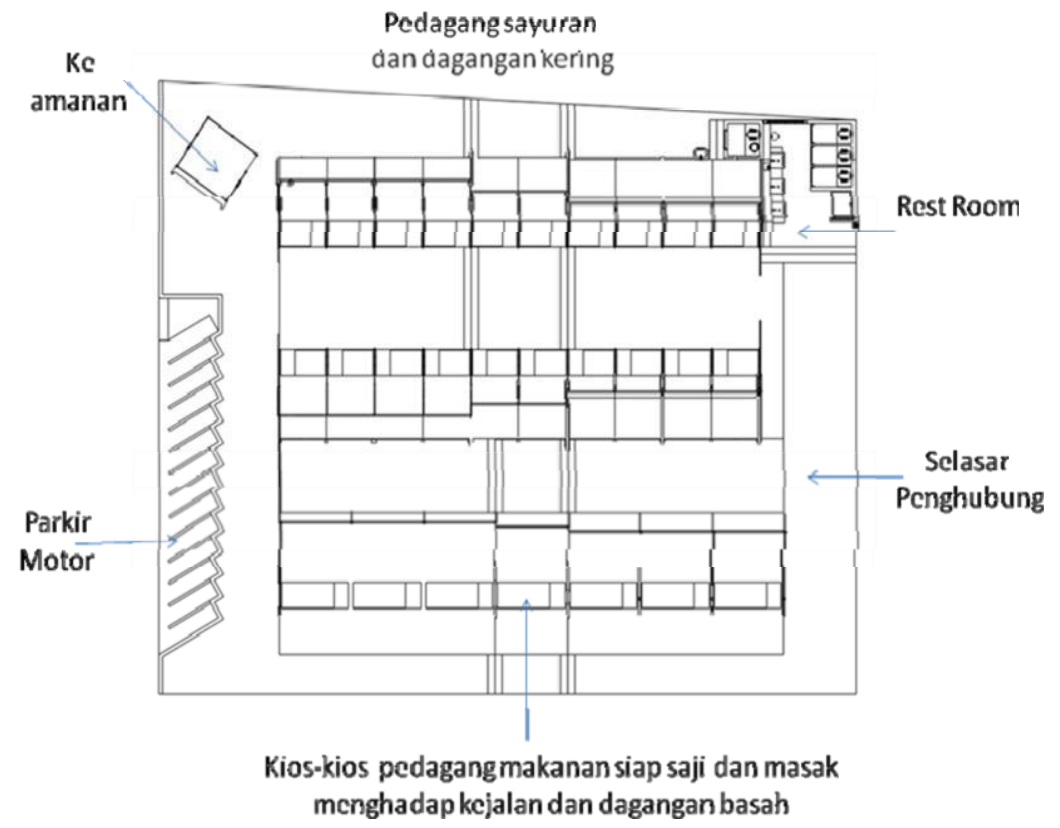

Gambar 14. Deret kios berhadapan dan deret kios menghadap jalan Kol Achmad Syam

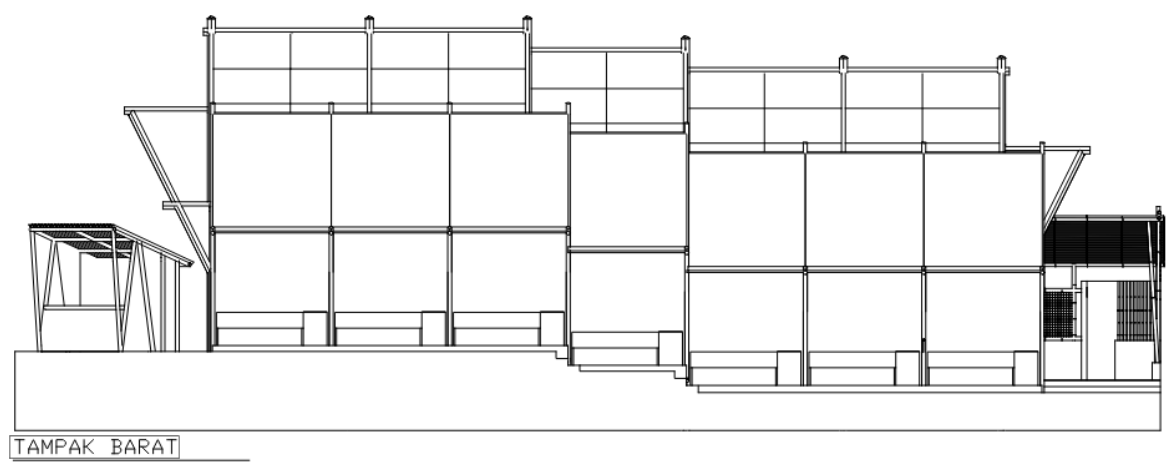

Gambar 15. Gambar bangunan pasar menghadap ke barat

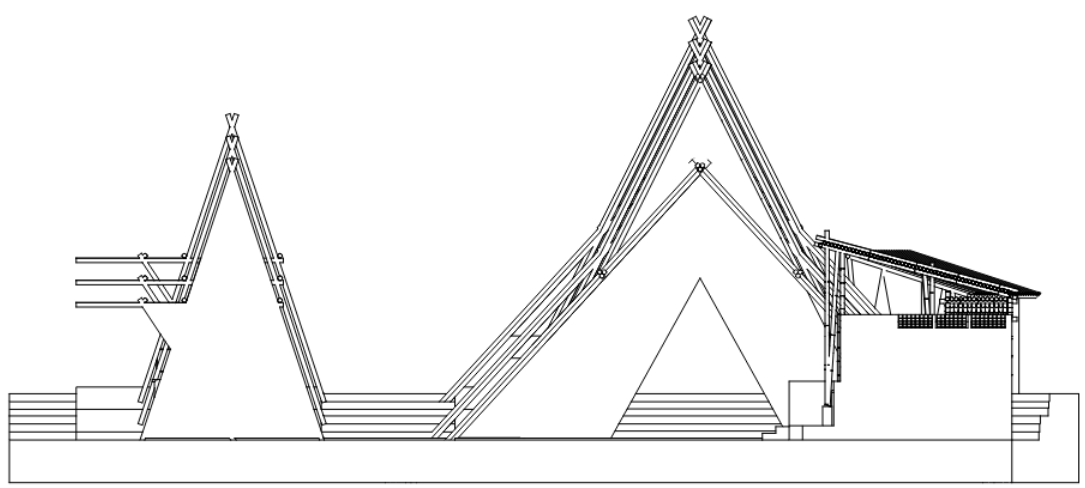

TAMPAK UTARA

Gambar 16. Deret kios berhadapan dan deret kios menghadap jalan Kol Achmad Syam

\section{KESIMPULAN}

SNI Pasar nomor 8152 tahun 2015 masih ideal untuk digunakan dalam penataan pasar tradisional namun perlu dievaluasi lagi tetang kalsifikasi dan jumlahnya. Kasus PKM 
penataan pasar tradisional di Bogor Timur perlu dipertimbangkan sebagai kajian menyusun Hal baru agar sesaui dengan kondisi waktu dan tuntutan.

\section{Ucapan Terima kasih}

Rasa terimakasih saya sampaikan untuk segenap jajaran pengelola PKM Universitas Tarumanagara mulai dari bagian administrasi hingga Manajer (ibu Endah Setioningsih)) dan Direktur (Bp. Yap Tjie Beng). Juga kepada pengurus pasar tradisional BSI yaitu ibu Sekretaris RW 05 (ibu Atun) dan Bapak Ketua RW 05 Kelurahan Baranang Siang Indah.

\section{REFERENSI}

ANALISIS DAMPAK PERTUMBUHAN PASAR MODEREN TERHADAP EKSISTENSI PASAR TRADISIONAL DI KABUPATEN BEKASI R u s h a m. Analisis Dampak Pertumbuhan Pasar Moderen Terhadap Eksistensi Pasar Tradisional di kabupaten Bekasi https://media.neliti.com/media/publications/154535-ID-analisis-dampakpertumbuhan-pasar-modere.pdf

Istijabatul Aliyah. Pemahaman Konseptual Pasar Tradisional Di Perkotaan. Cakra Wisata Vol 18 Jilid 2 Tahun 2017 https://www.google.com/search?q=jurnal+pasar\&oq=\&aqs=chrome.0.69i59i45018 .29655759j 0j15\&sourceid $=$ chrome\&ie $=U T F-8$

Lynch, Kevin. Site Planning. MIT Press, 1985.

Lynch, Kevin. The Image of the City. Cambridge: MIT Press, 1960.

Muzdalifah, Siti, Sukidin, Pudjo Suharso. KARAKTERISTIK PEDAGANG TRADISIONAL DI PASAR KEPATIHAN KABUPATEN JEMBER . Jurnal Ilmiah Ilmu Pendidikan, Ilmu Ekonomi, dan Ilmu Sosial ISSN 1907-9990 | E-ISSN 2548-7175 | Volume 13 Nomor 1 (2019) 94 DOI: 10.19184/jpe.v13i1.10426 C:/Users/USER/Downloads/10426-505-22791-1-10-20190421.pdf

Salura Purnama. "Menelusuri Arsitektur Masyarakat Sunda". CSS Publishing. 2008.

Salura Purnama ." Sundaness Architecture “PT. Rosda Inernasional. Bandung 2015.

SNI. Standar Nasional Indonesia $8152: 2015$.

Peraturan Presiden Republik Indonesia NOMOR 112 TAHUN 2017 TENTANG PENATAAN DAN PEMBINAAN PASAR TRADSIONAL, PUSAT PEREBELANJAAN DAN TOKO MODERN

Wicaksono Lulud $\mathrm{N}$ at all Persepsi Pedagang pasar Terhadap Program Perlindungan pasar Tradsional oleh pemerintah Semarang.Studi Kasus Pedagang Pasar peterongan Semarang. https://media.neliti.com/media/publications/111109-ID-persepsi-pedagang-pasarterhadap-program.pdf 